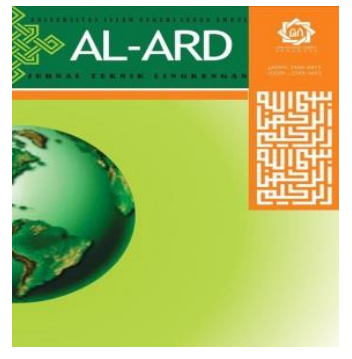

Al-Ard: Jurnal Teknik Lingkungan

Vol.5 No.2 - Maret 2020 (hal. 54-61)

http://jurnalsaintek.uinsby.ac.id/index.php/alard/index
Al-Ard:

Jurnal

Teknik Lingkungan

\title{
Produksi Lipid dari Mikroalga Scenedesmus sp. pada Media Limbah Cair Tahu dengan Variasi Konsentrasi Limbah dan Photoperiod
}

\author{
Shinta Elystia1, Dian Larasati², Sri Rezeki Muria ${ }^{3}$ \\ 1,2,3 Universitas Riau, Pekanbaru, Indonesia \\ Shintaelystia@yahoo.com
}

\begin{abstract}
Most energy needs in various countries are met from fossil fuels and has increased every year while petroleum reserves are only enough for 18 years into the futures. Various studies have been conducted out to utilize microalgae as raw material for biodiesel. Scenedesmus sp. has a growth rate and high lipid production, and has adequate fatty acids for synthesis of biodiesel and can utilize organic materials as nutrients in the form of tofu liquid waste so that the synergies between wastewater treatment and biomass production can run well. In this study examined the potential of microalgae Scenedesmus sp. with variations of tofu liquid waste in the cultivation medium $(0 \%, 20 \%, 40 \%, 60 \%, 80 \%, 100 \%)$ with the ratio of photoperiod light:dark $(16: 8,14: 10,12: 12$, and 24: 0$)$ and the time of data collection on days are $0,1,3,5,7,9,11$, and 13 . Based on the results of the study it was found that the highest lipid content was $27.12 \%$ at the added of $20 \%$ tofu liquid waste and photoperiod 12:12 with COD removal efficiency of 73.91\%.

Keywords: COD, Lipid, photoperiod, Scenedesmus sp., tofu liquid waste
\end{abstract}

\begin{abstract}
Abstrak
Kebutuhan energi di berbagai negara lebih banyak dipenuhi dari bahan bakar fosil dan mengalami peningkatan setiap tahunnya sementara cadangan minyak bumi hanya cukup untuk 18 tahun ke depan. Berbagai penelitian telah dilakukan untuk memanfaatkan mikroalga sebagai bahan baku biodiesel. Scenedesmus sp. memiliki tingkat pertumbuhan dan produksi lipid yang tinggi dan memiliki asam lemak yang memadai untuk sintesis biodiesel serta dapat memanfaatkan bahan organik sebagai nutrisi berupa limbah cair tahu sehingga sinergi antara pengolahan limbah cair dan produksi biomassa dapat berjalan dengan baik.. Pada penelitian ini akan diteliti potensi mikroalga Scenedesmus sp. dengan variasi pemberian limbah cair tahu dalam medium kultivasi $(0 \%, 20 \%, 40 \%, 60 \%, 80 \%, 100 \%)$ dengan perbandingan fotoperiod terang:gelap $(16: 8,14: 10,12: 12$, dan 24:0) dan waktu pengambilan data pada hari ke-0, 1, 3, 5, 7, 9, 11, dan 13. Berdasarkan hasil penelitian diperoleh kadar lipid tertinggi sebesar $27,12 \%$ pada pemberian limbah cair tahu 20\% dan fotoperiod 12:12 dengan efisiensi penyisihan COD sebesar 73,91\%.

Kata Kunci: COD, gelap:terang, Lipid, Limbah Cair Tahu, Scenedesmus sp.,
\end{abstract}

\section{PENDAHULUAN}

Kebutuhan energi di berbagai negara lebih banyak dipenuhi dari bahan bakar fosil dan mengalami peningkatan setiap tahunnya. Data Departemen Energi dan Sumber Daya Mineral menyebutkan bahwa minyak bumi mendominasi $54 \%$ penggunaan energi di Indonesia dan cadangan minyak bumi tersebut hanya cukup untuk 18 tahun ke depan (Assadad dkk, 2010). Salah satu cara untuk mengatasi permasalahan tersebut adalah dengan memanfaatkan mikroalga. Mikroalga adalah sejenis makhluk hidup unisel p-ISSN: 2460-8815 , e-ISSN: 2549-1652 berukuran antara 1 mikrometer sampai ratusan mikrometer, membutuhkan karbon dioksida, beberapa nutrien dan cahaya untuk berfotosintesis sehingga menghasilkan biomassa (Widjaja, 2009). Harun dkk (2010) memaparkan beberapa produk yang dapat dihasilkan dari mikroalga, diantaranya produk energi seperti biodiesel, serta untuk pengolahan limbah cair industri. Menurut Hadiyanto dan Azim (2012), limbah cair organik akan lebih aman dibuang ke lingkungan setelah digunakan sebagai medium mikroalga, sementara biomassa yang 
dihasilkan oleh mikroalga dapat difokuskan untuk energi, sehingga sinergi antara pengolahan limbah cair dan produksi biomassa dapat berjalan dengan baik.

Berbagai penelitian telah dilakukan untuk memanfaatkan mikroalga sebagai bahan baku biofuel (Assadad dkk, 2010). Penelitian yang telah dilakukan cenderung memanfaatkan mikroalga sebagai bahan baku biodiesel (Widjaja, 2009). Hal ini dilakukan mengingat kandungan lipid yang ada pada mikroalga cukup tinggi. Lipid di dalam sel mikroalga berfungsi sebagai sumber energi cadangan apabila sel kekurangan karbohidrat sebagai sumber energi utama (Widianingsih dkk, 2011). Menurut Nurlita dkk (2007), semakin banyak kandungan asam lemak dalam suatu bahan maka semakin besar pula potensi bahan tersebut untuk dapat menghasilkan biodiesel. Scenedesmus dianggap sebagai mikroalga yang menjanjikan untuk produksi biofuel karena spesies alga ini memiliki tingkat pertumbuhan dan produksi lipid yang tinggi, dan memiliki asam lemak yang memadai untuk sintesis biodiesel (Soares dkk, 2017). Mikroalga Scenedesmus sp. mempunyai kandungan minyak nabati yang cukup banyak sekitar 40,8 - 53,9 mg/liter/hari (Mata dkk, 2010).

Industri di Indonesia sebagian besar menghasilkan limbah yang tidak dimanfaatkan secara optimal, salah satunya limbah dari industri tahu. Hal ini sering kali menjadi masalah bagi lingkungan sekitarnya karena dapat menyebabkan pencemaran dan terganggunya kualitas lingkungan perairan (Rossiana, 2006). Senyawa-senyawa organik di dalam air buangan industri tahu dapat berupa protein $40-60 \%$, karbohidrat 25 $50 \%$, dan lemak 10\% (Herlambang, 2002). Secara teknis, mikroalga menyerap kandungan senyawa organik dan nutrien yang masih tersisa dalam limbah, kemudian menghasilkan oksigen yang dapat menurunkan kadar COD dalam limbah lewat bantuan bakteri pengurai zat organik (Hadiyanto dan Azim, 2012). Berdasarkan kandungan nutrisi yang masih terdapat pada limbah cair tahu, maka pemanfaatannya sebagai medium alternatif pertumbuhan mikroalga merupakan salah satu bentuk pemecahan masalah limbah cair tahu (Muttaqin dan Wachda, 2016).

Dalam penelitian ini akan diteliti potensi mikroalga Scenedesmus sp. dengan variasi pemberian limbah cair tahu dalam medium kultivasi yang didukung oleh variasi fotoperiod dan waktu pengambilan sampel yang berbeda untuk mendapatkan kadar lipid tertinggi sebagai bahan baku biodiesel serta pengaruhnya dalam menyisihkan parameter COD dalam limbah cair tahu.

\section{METODE PENELITIAN Alat dan Bahan}

Mikroalga Scenedesmus sp. yang diperoleh dari Indonesian Culture Collection (InaCC), Research Center for Biology, Lembaga Ilmu Pengetahuan Indonesia (LIPI), Bogor. Bogor. Kultur murni Scenedesmus sp. sebanyak $5 \mathrm{ml}$ dibiakkan dalam $250 \mathrm{ml}$ Medium Basal Bold (MBB) pada suhu ruang, dan fotoperiod 12:12 dengan diberi aerasi selama 2 minggu.

\section{Persiapan Media Kultur}

Medium Basal Bold (MBB) berupa $\mathrm{KH}_{2} \mathrm{PO}_{4}$ $\mathrm{CaCl}_{2} \cdot \mathrm{H}_{2} \mathrm{O}, \mathrm{MgSO}_{4} .7 \mathrm{H}_{2} \mathrm{O}, \mathrm{NaNO}_{3}, \mathrm{~K}_{2} \mathrm{HPO}_{4}, \mathrm{NaCl}$, $\mathrm{KOH}, \mathrm{FeSO}_{4} .7 \mathrm{H}_{2} \mathrm{O}, \mathrm{H}_{3} \mathrm{BO}_{3}$, EDTA, dan larutan trace element metal berupa $\mathrm{MnCl}_{2} .4 \mathrm{H}_{2} \mathrm{O}$, $\mathrm{ZnSO}_{4} \cdot 7 \mathrm{H}_{2} \mathrm{O}, \quad \mathrm{NaMoO}_{4} \cdot 2 \mathrm{H}_{2} \mathrm{O}, \quad \mathrm{CuSO}_{4} \cdot 5 \mathrm{H}_{2} \mathrm{O}$, $\mathrm{Co}\left(\mathrm{NO}_{3}\right)_{2} \cdot 6 \mathrm{H}_{2} \mathrm{O}$. Preparasi dilakukan dengan cara menambahkan $10 \mathrm{ml}$ dari larutan MBB kedalam erlenmeyer 1 liter kemudian ditambahkan akuades. Larutan yang telah dihomogenkan tersebut selanjutnya disterilisasi menggunakan autoclave pada suhu $121^{\circ} \mathrm{C}$ selama 15 menit dengan tekanan 2 atm (Fadilla, 2010).

Limbah cair tahu dari industri tahu rumahan jalan Garuda Ujung, Kelurahan Tangkerang Tengah, Kecamatan Marpoyan Damai, Pekanbaru. Kemudian dilakukan sterilisasi menggunakan autoclave pada suhu $121^{\circ} \mathrm{C}$ selama 15 menit. Preparasi limbah cair tahu dilakukan sesuai perlakuan penelitian yaitu dengan volume $0 \%, 20 \%, 40 \%, 60 \%$, $80 \%, 100 \%$ masing-masing perlakuan akan dimasukkan ke dalam erlenmeyer $500 \mathrm{ml}$ yang sudah terisi $2 \mathrm{ml}$ mikroalga Scenedesmus sp. dengan batas volume kultivasi sampai $250 \mathrm{ml}$.

\section{Kultivasi Mikroalga}

Alat yang digunakan dalam penelitian ini adalah chamber cahaya berukuran $100 \mathrm{~cm}$ x $30 \mathrm{~cm} \quad$ x $40 \mathrm{~cm}$. Erlenmeyer $500 \mathrm{ml}$ digunakan sebagai wadah kultivasi mikroalga Scenedesmus sp. Mikroalga dalam erlenmeyer diaerasi menggunakan aerator (aquarium pump) yang berfungsi untuk mengontakkan mikroalga dengan media tumbuh dan nutrien (limbah cair tahu). Sumber cahaya pada chamber ini menggunakan lampu TL (Tube Lamp). Rak ini dilapisi alumunium foil yang berfungsi untuk menjaga agar intensitas 
cahaya yang dihasilkan terkuantisasi sehingga mikroalga dalam erlenmeyer mendapatkan cahaya yang maksimal (Daniyati dkk, 2012).

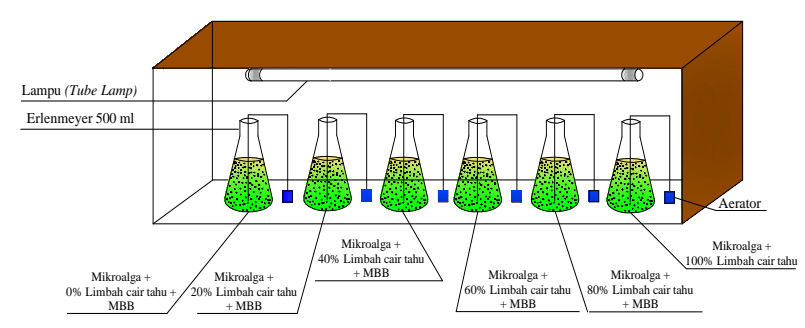

Gambar 1. Chamber Cahaya

Erlenmeyer $500 \mathrm{ml}$ diisi dengan medium kultur berupa limbah cair tahu bersamaan dengan Medium Basal Bold (MBB) sesuai masing-masing variasi perlakuan. Kultur mikroalga Scenedesmus sp. ditambahkan sebanyak $2 \mathrm{ml}$ yang sudah dihitung jumlah sel awalnya. Dari 7 variasi medium, masingmasingnya dilakukan variasi fotoperiod (periode terang:gelap) yaitu 16:8, 14:10, 12:12, dan 24:0. Selanjutnya erlenmeyer ditutup rapat untuk mencegah kontaminasi, diberi aerasi dan lubang untuk udara keluar serta pencahayaan dari lampu TL (Tube Lamp) (Prihantini dkk, 2007) dengan intensitas cahaya 3000 lux (Widianingsih dkk, 2012).

\subsection{Analisa Data}

\subsubsection{Perhitungan Jumlah Sel Mikroalga}

Selama proses kultivasi, perhitungan jumlah sel mikroalga dilakukan pada variasi waktu $0,1,3,5,7,9,11$, dan 13 hari dimulai dari $t_{0}$ (hari ke-0) hingga $t_{13}$ (hari ke-13). Sebanyak $1 \mathrm{ml}$ kultur diambil dari tiap-tiap perlakuan. Kemudian jumlah sel dihitung menggunakan alat thomacytometer. Jumlah sel/ml dihitung menggunakan persamaan berikut :

Jumlah sel $\mathrm{ml}=\frac{\text { Jumlah sel rata-rata setiap petak } \times 1000}{\mathrm{~L}\left(\mathrm{~mm}^{2}\right) \times \mathrm{K}(\mathrm{mm})} \times \mathrm{P}$

Dimana : $\mathrm{P}=$ Faktor pengenceran

$$
\begin{aligned}
& \mathrm{L} \quad=\quad \text { Luas petak } \\
& (0,2 \times 0,2) \mathrm{mm}^{2}=\left(0,04 \mathrm{~mm}^{2}\right) \\
& \mathrm{K}=\text { Kedalaman petak }(0,1 \mathrm{~mm})
\end{aligned}
$$

\section{Analisa Lipid}

Analisis kadar lipid diawali dengan pengujian berat kering atau bobot biomassa yang dilakukan dengan cara $1 \mathrm{ml}$ sampel disaring menggunakan kertas saring dan dipanaskan pada suhu $105^{\circ} \mathrm{C}$. Sedangkan ekstraksi lipid dilakukan dengan metode Bligh-Dyer. Sel mikroalga sebanyak $1 \mathrm{ml}$ diekstraksi dengan larutan kloroform:metanol $(2: 1 \mathrm{v} / \mathrm{v})$ sehingga terpisah menjadi lapisan cairan kloroform dan metanol. Kemudian ditambahkan metanol dan air untuk menghasilkan rasio pelarut akhir dari kloroform:metanol:air sebesar 1:1:0,9. Total lipid ditentukan secara gravimetri (Putri, 2012).

$$
\% \text { Total lipid }=\frac{\mathrm{Lw}}{\mathrm{Bw}} \times 100
$$

Dimana:

$\mathrm{Lw}=$ Bobot lipid (gram)

$\mathrm{Bw}=$ Bobot Biomassa (gram)

\subsubsection{Analisa Chemical Oxygen Demand (COD)}

Analisis kadar COD dilakukan diawal sebelum kultivasi dan setelah kultivasi. Analisis parameter COD mengacu pada SNI 6989.73:2009 dengan metode refluks tertutup secara titrimetri. Untuk mengetahui efisiensi penurunan parameter COD digunakan persamaan berikut:

$$
\begin{aligned}
\text { Efisiensi (\%) } & =\frac{\mathrm{C}_{\text {in }}-\mathrm{C}_{\text {ef }}}{\mathrm{C}_{\text {in }}} \times 100 \% \\
\text { Dimana: } C_{\text {in }}= & \text { Konsentrasi influen (mg/L) } \\
C_{\text {ef }}= & \text { Konsentrasi efluen (mg/L) }
\end{aligned}
$$

\section{HASIL DAN PEMBAHASAN}

\subsection{Pengaruh Volume Limbah Cair Tahu dan Fotoperiod terhadap Jumlah Sel Mikroalga Scenedesmus sp.}

Perhitungan jumlah sel dilakukan setiap hari ke-0, 1, 3, 5, 7, 9, 11, dan 13 menggunakan alat thomacytometer. Hasil penelitian menunjukkan bahwa kultur yang ditumbuhkan dalam medium limbah cair tahu dan Medium Basal Bold (MBB) menghasilkan kepadatan sel yang berbeda. Hal tersebut menandakan bahwa variasi media perlakuan yang digunakan berpengaruh terhadap pertumbuhan sel mikroalga Scenedesmus sp. 


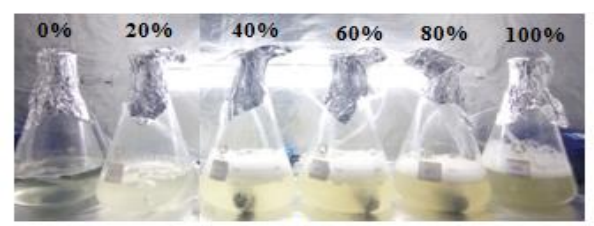

(a)

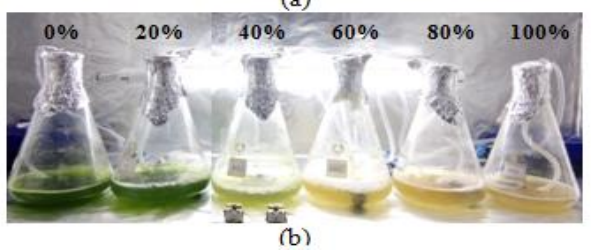

Gambar 2. Kultivasi mikroalga Scenedesmus sp. pada variasi volume limbah cair tahu (a) hari ke-0 dan (b) hari ke-13

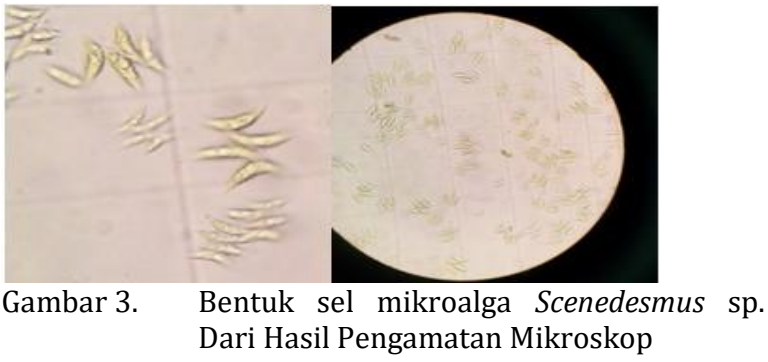

Berdasarkan hasil perhitungan jumlah sel, kepadatan sel mikroalga Scenedesmus sp. tertinggi terdapat pada perlakuan $0 \%$ limbah cair tahu. Menurut Salim (2013), penggunaan MBB pada kultur tunggal yang sama dengan medium yang digunakan untuk isolasi jenis Scenedesmus sp. memungkinkan sel dari spesies ini dengan cepatnya bereproduksi. Hal tersebut menunjukkan bahwa fase adaptasi sel Scenedesmus sp. berlangsung cepat dan pertumbuhan sel lebih banyak. Pada perlakuan medium dengan penambahan limbah cair tahu, sel memerlukan fase adaptasi lebih lama dan pertumbuhan menjadi lebih lambat. Hal ini sesuai dengan penelitian yang dilakukan oleh Widayat dan Hadiyanto (2015) dengan mikroalga Nannochloropsis sp. pada medium 20\% limbah cair tahu memerlukan tahap pre-culture terlebih dahulu sehingga pertumbuhannya lebih lambat dibanding medium air laut.

Pada perlakuan $60 \%$, 80\%, dan $100 \%$ limbah cair tahu, pertumbuhan jumlah sel cenderung lebih sedikit. Hal ini disebabkan kandungan volume limbah cair tahu yang lebih besar berarti memiliki kandungan unsur hara yang berlebih sehingga pertumbuhan sel menjadi tidak optimal. Hal ini sama dengan penelitian yang dilakukan oleh Salim (2013) yang mana populasi puncak terendah dicapai pada perlakuan $50 \%$ limbah cair tahu pada hari ke-13. Pada penelitian ini, populasi puncak pada perlakuan volume limbah cair tahu yang berlebih yaitu perlakuan $60 \%$ hanya mencapai $8 \times 10^{5} \mathrm{sel} / \mathrm{ml}$ pada hari ke-13 untuk fotoperiod 12:12. Ketersediaan unsur hara yang berlebihan dapat menurunkan jumlah sel karen9a unsur hara dari limbah cair tahu dapat menyebabkan inhibisi bagi sel Scenedesmus sp. sehingga setelah mencapai puncak maka segera pertumbuhan jumlah sel Scenedesmus sp. menurun (Salim, 2013). Selain itu, menurut Muttaqin dan Wachda (2016) semakin tinggi konsentrasi medium akan menyebabkan pertumbuhan berkurang karena adanya peningkatan kepekatan medium sehingga menghambat cahaya masuk ke dalam medium.

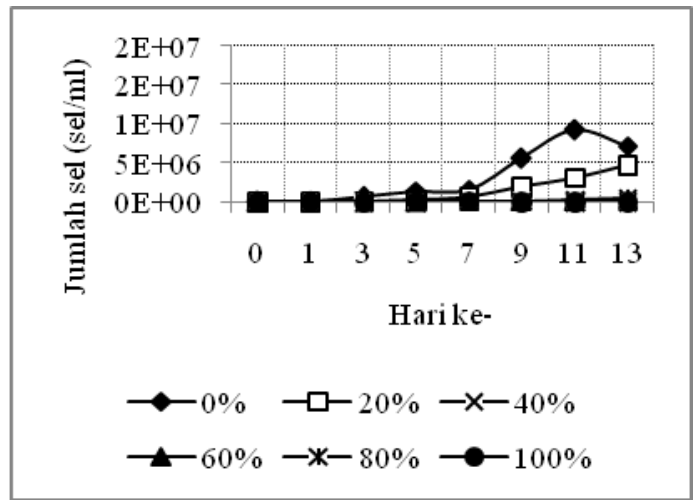

(a)

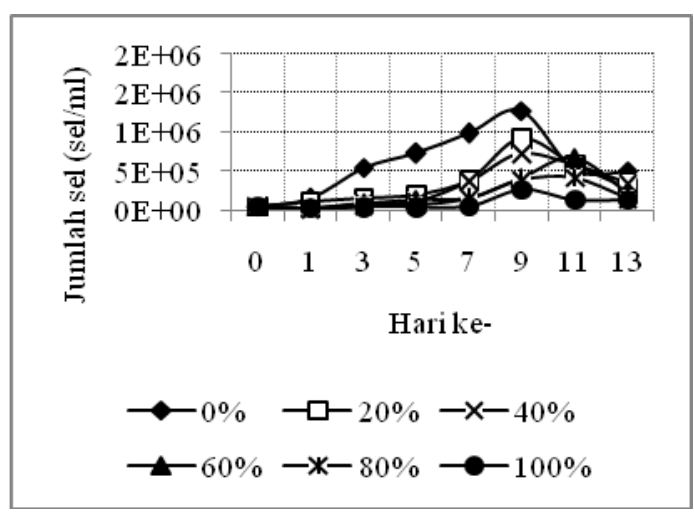

(b)

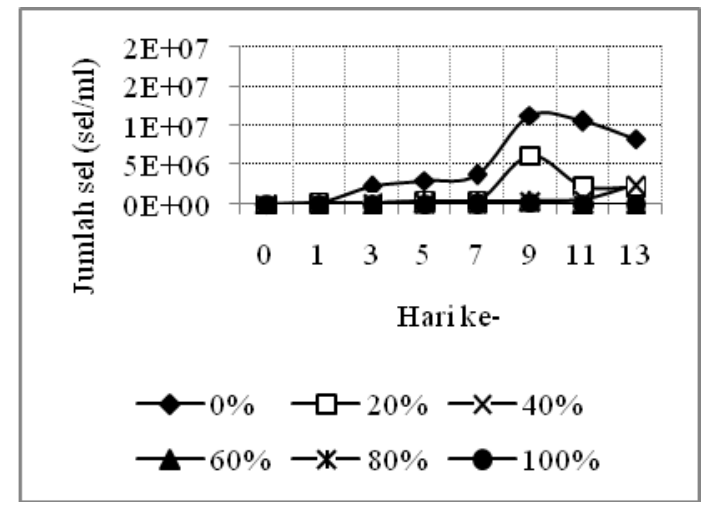

(c) 


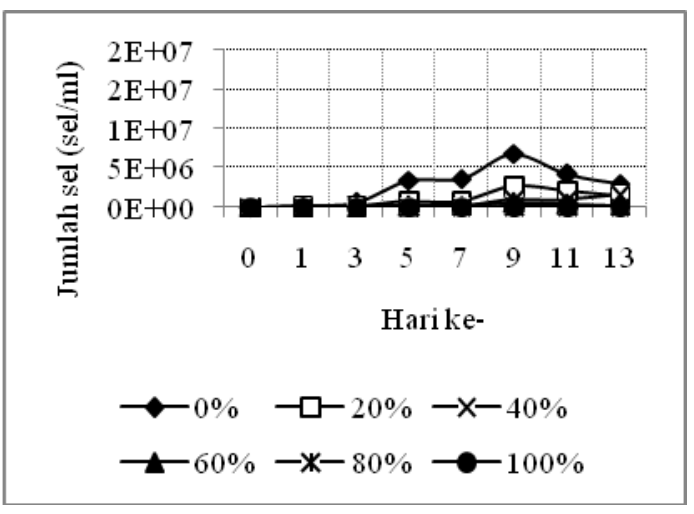

(d)

Gambar 4. Grafik hubungan volume limbah cair tahu terhadap jumlah sel pada variasi fotoperiod (a) 16:8, (b) 14:10, (c) 12:12, dan (d) 24:0

Fotoperiod merupakan salah satu faktor yang penting dalam penentuan tingkat keberhasilan fotosintesis oleh mikroalga (Widianingsih dkk, 2012). Adanya variasi fotoperiod mempengaruhi pertumbuhan sel mikroalga Scenedesmus sp. Pada Gambar 4, jumlah sel tertinggi terlihat pada perlakuan fotoperiod 12:12 untuk setiap variasi pemberian limbah cair tahu. Hal ini sesuai dengan penelitian Manullang dkk (2013) dengan mikroalga yang berbeda yaitu Spirulina platensis pertumbuhan lebih cepat pada fotoperiod 12:12. Hasil ini juga diperkuat oleh penelitian Latiffi dkk (2017) yang melaporkan bahwa pertumbuhan mikroalga Scenedesmus sp. yang terbaik pada fotoperiod 12:12. Bouterfas dkk (2006) menyatakan bahwa fotoperiod 12:12 memungkinkan keseimbangan yang terbentuk antara fenomena anabolik dan katabolik selama siklus fotoperiod. Bouterfas dkk (2006) juga menambahkan bahwa untuk aplikasi industri, fotoperiod 12:12 dianggap sebagai kondisi optimal untuk pertumbuhan mikroalga. Cahaya dibutuhkan pada fase fotokimia untuk menghasilkan energi berupa ATP dan NADPH, sedangkan kondisi gelap dibutuhkan pada fase biokimia untuk sintesis molekul-molekul metabolik yang berperan dalam proses pertumbuhan.

Pada kurva pertumbuhan terkadang memperlihatkan pola pertumbuhan yang tidak lengkap, bukan karena tidak adanya salah satu fase, tetapi fase tersebut berlangsung sangat cepat sehingga sulit digambarkan (Andriyono, 2001). Hal ini dapat dilihat pada Gambar 3 yang menunjukkan fase stasioner masingmasing variasi tidak terlihat nyata. Fase pertumbuhan mikroalga diawali dengan fase adaptasi yaitu penyesuaian mikroalga pada lingkungan yang baru, kemudian dilanjutkan dengan fase eksponensial. Menurut Rusyani (2001), pada awal kultur kandungan nutrien masih tinggi sehingga dapat dimanfaatkan oleh populasi mikroalga dengan baik untuk reproduksi dan pertumbuhan yang ditandai dengan peningkatan jumlah sel.

Jumlah populasi meningkat namun tidak ada penambahan nutrien, sedangkan pemanfaatan nutrien oleh mikroalga terus berlanjut sehingga terjadi persaingan antar mikroalga yang menyebabkan terjadinya penurunan pertumbuhan. Setelah sel mencapai puncak pertumbuhan, maka tidak terjadi lagi penambahan jumlah sel lagi karena pada fase stasioner terjadi keseimbangan antara nutrisi dengan jumlah sel di media kultur (Rusyani, 2001). Kemudian sel memasuki fase kematian yang disebabkan oleh mulai berkurangnya nutrien yang tersedia sehingga tidak mampu mendukung pertumbuhan sel. Fase kematian juga ditandai dengan perubahan kondisi media seperti warna dan pH medium (Irianto, 2011).

\subsection{Pengaruh Volume Limbah Cair Tahu dan Fotoperiod terhadap Kadar Lipid Mikroalga Scenedesmus sp.}

Berdasarkan seluruh variasi volume limbah cair tahu pada Gambar 5, lipid paling tinggi dihasilkan pada perlakuan $20 \%$ dan $0 \%$ limbah cair tahu untuk setiap variasi fotoperiod. Hal ini sesuai dengan hasil penelitian Widayat dan Hadiyanto (2015) dengan mikroalga Nannochloropsis sp. yang dikultur pada $20 \%$ limbah cair tahu menghasilkan lipid mencapai 34,25\%, sedangkan pada $0 \%$ limbah cair tahu menghasilkan lipid sebesar $32,50 \%$. Menurut Muttaqin dan Wachda (2016), kandungan lipid sangat bergantung pada ion ammonium dan fosfat, karena dua ion tersebut berguna sebagai penyusun struktur lipid. Ion ammonium (sumber nitrogen) yang sudah terdapat pada medium limbah cair tahu dapat digunakan secara langsung untuk metabolisme sel. Sedangkan pada medium MBB, ion nitrat harus diubah dulu menjadi ion ammonium agar bisa digunakan oleh sel untuk proses fotosintesis sehingga memiliki efek pada lipid yang dihasilkan. Lipid berfungsi sebagai sumber energi cadangan apabila sel kekurangan karbohidrat (Widianingsih dkk, 
2011). Pada penelitian ini, rendahnya kadar lipid yang dihasilkan pada volume limbah cair tahu yang lebih besar $(40 \%, 60 \%, 80 \%$, dan $100 \%$ ) disebabkan energi hasil fotosintesis disimpan sebagai bentuk proses adaptasi sel untuk mempertahankan hidup pada lingkungan yang ekstrim atau pada keadaan diluar kondisi optimal untuk tumbuh. Hal tersebut menyebabkan pertumbuhan sel lebih lambat pada perlakuan volume limbah tahu yang lebih besar seperti pada Gambar 5 .

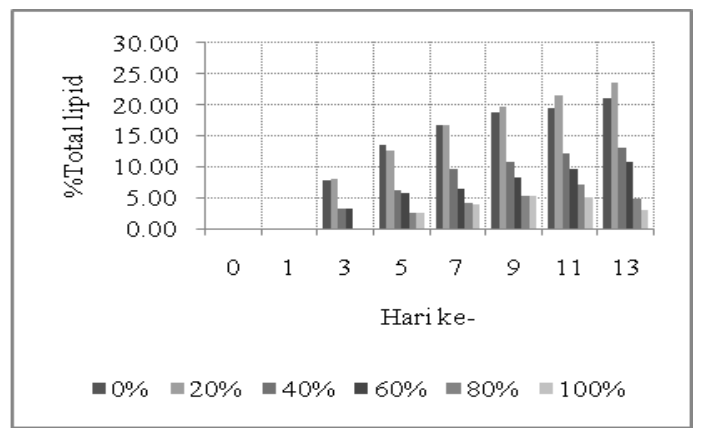

(a)

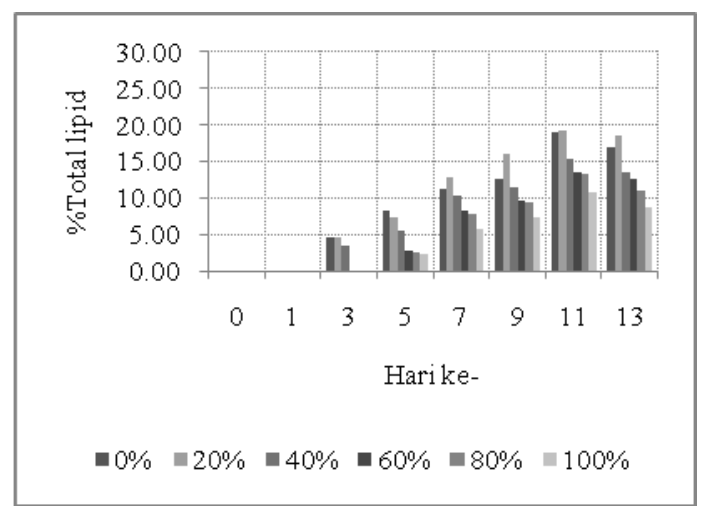

(b)

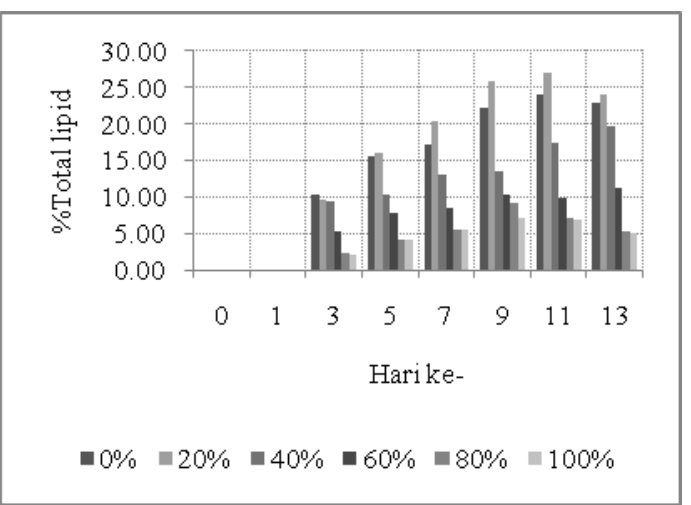

(c)

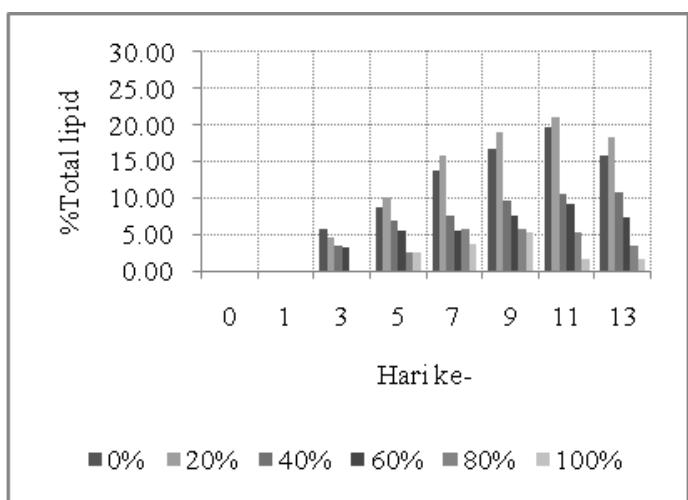

(d)

Gambar 5. Grafik hubungan volume limbah cair tahu terhadap kadar lipid pada variasi fotoperiod (a) $16: 8$, (b) $14: 10$, (c) $12: 12$, dan (d) $24: 0$

Berdasarkan Gambar 5 diatas, kadar lipid tertinggi yang dihasilkan pada perlakuan $20 \%$ limbah cair tahu berturut-turut yaitu 27,12\% (fotoperiod 12:12), 23,61\% (fotoperiod 16:8), $21,05 \%$ (fotoperiod 24:0), dan 19,30\% (fotoperiod 14:10). Menurut Harahap dkk (2013) pembelahan sel terjadi selama periode gelap, sedangkan proses metabolisme seperti pembentukan pigmen, sintesa lipid dan asam terjadi selama periode terang. Oleh sebab itu pada penelitian ini, pembelahan sel yang terjadi secara cepat pada 12 jam periode gelap menyebabkan sintesa lipid pada 12 jam periode terang menjadi meningkat. Hal ini sesuai dengan hasil penelitian Widianingsih dkk (2012) yang menyatakan bahwa untuk mendapatkan kandungan lipid total yang maksimal, maka Nannochloropsis oculata harus dikultur pada fotoperiod 12:12 dengan panen pada saat kultur memasuki fase stasioner yaitu $31,8 \%$. Lebih kecilnya nilai lipid total pada perlakuan 24:0 disebabkan adanya proses photoinhibition pada kultur sehingga dapat menyebabkan rusaknya sel-sel yang mengandung lipid (Widianingsih dkk, 2012).

Pada penelitian ini, jika ditinjau dari pola pertumbuhan Scenedesmus sp., kadar lipid tertinggi yang dihasilkan berada pada fase stasioner, yaitu antara hari ke-9 sampai 13 untuk perlakuan 20\% limbah cair tahu. Menurut Harahap dkk (2013), pada fase stasioner sel akan memiliki kadar lipid yang lebih besar dibanding pada fase eksponensial, karena pada fase eksponesial seluruh nutrien yang dibentuk pada sel masih digunakan untuk pertumbuhan. Menurut Safitri dkk (2013) produksi lipid atau penumpukan cadangan lemak terjadi pada fase stasioner, yaitu ketika nutrien utama seperti nitrogen 
untuk sintesa protein atau untuk produksi biomassa sudah tidak mencukupi. Muttaqin dan Wachda (2016) menyatakan jika jumlah sel berkurang, maka lipid yang dihasilkan berkurang. Hal ini sesuai dengan hasil penelitian yang dapat dilihat pada Gambar 5 yaitu pada saat sel memasuki fase kematian, lipid yang dihasilkan semakin berkurang.

\subsection{Pengaruh Volume Limbah Cair Tahu dan Fotoperiod terhadap Efisiensi Penurunan Parameter COD}

Berdasarkan Tabel 1, pada masingmasing medium kultur menunjukkan hasil konsentrasi COD awal dan akhir kultivasi. Penambahan limbah cair tahu ke dalam medium kultivasi selain untuk memberikan nutrisi pada pertumbuhan mikroalga Scenedesmus sp., juga bertujuan untuk menurunkan kadar COD yang terkandung dalam limbah cair tahu. Pengolahan limbah cair tahu menggunakan mikroalga memberikan hasil yang cukup baik.

Tabel 1 Hasil Konsentrasi COD Awal dan Akhir Kultivasi

\begin{tabular}{cccccc}
\hline \multirow{2}{*}{$\begin{array}{c}\text { Limbah } \\
\text { Cair Tahu }\end{array}$} & $\begin{array}{c}\text { COD } \\
\text { awal } \\
(\mathrm{mg} / \mathrm{L})\end{array}$ & $16: 8$ & $14: 10$ & $12: 12$ & $24: 0$ \\
\hline $0 \%$ & 450 & 250 & 250 & 150 & 200 \\
\hline $20 \%$ & 1150 & 450 & 500 & 300 & 400 \\
\hline $40 \%$ & 2200 & 1250 & 1300 & 1000 & 1100 \\
\hline $60 \%$ & 3250 & 2200 & 2250 & 2050 & 2150 \\
\hline $80 \%$ & 4450 & 3250 & 3350 & 3150 & 3200 \\
\hline $100 \%$ & 5400 & 4600 & 4650 & 4200 & 4600 \\
\hline
\end{tabular}

Pada Gambar 6 menunjukkan bahwa dengan menggunakan mikroalga jenis Scenedesmus sp. dapat menurunkan COD hingga $73,91 \%$ pada penambahan $20 \%$ limbah cair tahu. Hal ini sesuai dengan hasil penelitian Widayat dan Hadiyanto (2015) yang menunjukkan bahwa pada variabel $20 \%$ limbah cair tahu, mikroalga Nannochloropsis sp. mampu menurunkan COD hingga 77,40\%. Menurut Widayat dan Hadiyanto (2015), pertumbuhan mikroalga yang optimal diindikasikan dengan penurunan COD yang lebih besar. Hal ini sebagai bukti adanya proses penguraian dan pemanfaatan senyawa organik oleh mikroalga untuk pertumbuhan.

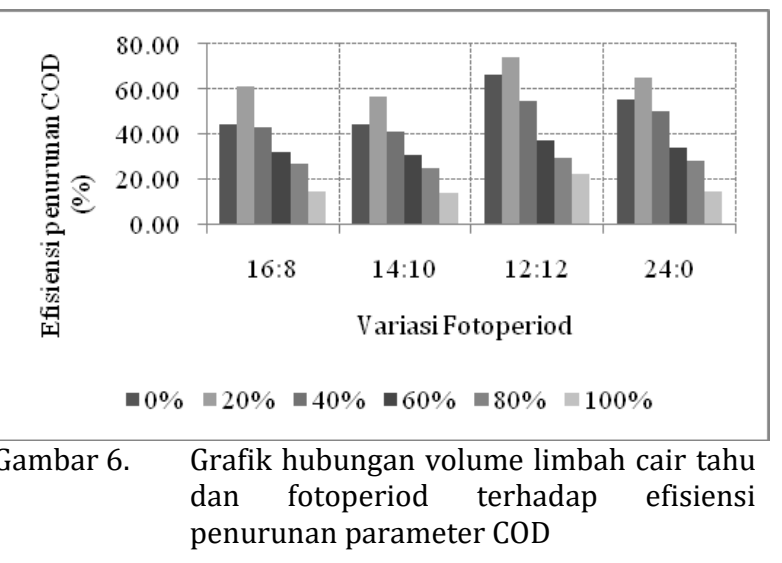

\section{KESIMPULAN}

Kultivasi dengan variasi pemberian limbah cair tahu dan fotoperiod memberikan pengaruh terhadap kadar lipid mikroalga Scenedesmus sp. Kadar lipid tertinggi diperoleh pada pemberian limbah cair tahu $20 \%$ dan fotoperiod 12:12 pada hari ke- 11 yaitu sebesar $27,12 \%$ dengan efisiensi penyisihan COD sebesar 73,91\%.

\section{DAFTAR PUSTAKA}

Andriyono, S. 2001. Pengaruh Periode Penyinaran terhadap Pertumbuhan Isochrysis galbana klon Tahiti. Skripsi. Bogor: Institut Pertanian Bogor.

Assadad, L., Utomo, B.S.B., dan Sari, R.N. 2010. Pemanfaatan Mikroalga Sebagai Bahan Baku Bioetanol. Jurnal Squalen. 5(2):5158.

Badan Standarisasi Nasional. 2009. SNI 6989.73:2009. Cara Uji Kebutuhan Oksigen Kimiawi (Chemical Oxygen Demand (COD)) dengan refluks tertutup secara titrimetri.

Bouterfas, R., Belkoura, M., dan Dauta, A. 2006. The Effects of Irradiance and Photoperiodon The Growth Rate of Three Freshwater Green Algae Isolated from A Eutrophic Lake. Jurnal Limnetica. 25(3):647-656.

Daniyati, R., Yudoyono, G., dan Rubiyanto, A. 2012. Desain Closed Photo bioreaktor Chlorella vulgaris sebagai Mitigasi $\mathrm{CO}_{2}$. Jurnal Sains dan Seni. 1:1-5.

Fadilla, Z. 2010. Pengaruh Konsentrasi Limbah Cair Tahu Terhadap Pertumbuhan Mikroalga Scenedesmus sp. Skripsi. Jakarta: Universitas Islam Negeri Syarif Hidayatullah.

Hadiyanto, dan Azim, M. 2012. Mikroalga Sumber Pangan dan Energi Masa Depan. Semarang: UPT UNDIP Press. 
Harahap, P.S., Susanto, A.B., Susilaningsih, D., Delicia, Y.R. 2013. Pengaruh Substitusi Limbah Cair Tahu untuk Menstimulasi Pembentukan Lipida pada Chlorella sp. Journal of Marine Research. 2(1):80-86.

Harun, R., Singh, M., Forde, G.M., dan Danquah, M.K. 2010. Bioprocess Engineering of Microalgae to Produce a Variety of Consumer Products. Renewable and Sustainable Energy Reviews. 14:10371047.

Herlambang, A. 2002. Teknologi Pengolahan Limbah Cair Industri Tahu, Pusat Pengkajian dan Penerapan Teknologi Lingkungan (BPPT) dan Badan Pengendalian Dampak Lingkungan Samarinda.

Irianto, D. 2011. Pemanfaatan Mikroalga Laut Scenedesmus sp. Sebagai Penyerap Bahan Kimia Berbahaya dalam Air Limbah Industri .Skripsi. Bogor: Institut Pertanian Bogor.

Latiffi, N.A.A, Mohamed, R.M.S.R., Apandi, N.M., dan Tajuddin, R.M. 2017. Experimental Assessment on Effects of Growth Rates Microalgae Scenedesmus sp. Different Conditions of $\mathrm{pH}$, Temperature, Light Intensity and Photoperiod. Jurnal Key Engineering Materials. 744:546-551.

Manullang, C., Widianingsih, dan Endrawati, $\mathrm{H}$. 2012. Densitas dan Kandungan Total Lipid Mikroalga Spirulina platensis yang Dikultur pada Tingkatan Perbedaan Fotoperiod. Journal of Marine Research. 1(1):24-28.

Mata, T.M., Martins, A.A. dan Caetano, N.S. 2010. Microalgae for Biodiesel Production and Other Applications: A review. Renewable and Sustainable Energy Reviews. 14:217-232.

Muttaqin, S.S., dan Wachda. 2016. Peningkatan Kandungan Lipid pada Kultur Arthrospira Maxima (Setchell \& N.L Gardner) sebagai Biodiesel dengan Medium Limbah Cair Tahu. Inovation Science Writing Competition (Instinct). Yogyakarta: Universitas Gadjah Mada.

Nurlita, A., Zuhdi, A.M.F, dan Sukesi. 2007. Potensi Mikroalga Skeletonema costatum, Chlorella vulgaris, dan Spirulina platensis sebagai Bahan Baku Biodiesel. Jurnal Biologi. 1-10.

Prihantini, N.B, Damayanti, D., dan Yuniati, R. 2007. Pengaruh Konsentrasi Medium Ekstrak Tauge (MET) Terhadap
Pertumbuhan Scenedesmus Isolat Subang. Jurnal Makara Sains. 11(1):1-9.

Putri, E.V. 2012. Cultivation of Microalgae Using Palm Oil Mill Effluent for Lipid Production. Thesis. Universiti Teknologi Malaysia.

Rossiana, N. 2006. Uji Toksisitas Limbah Cair Tahu Sumedang Terhadap Reproduksi Daphnia carinata King. Laporan Penelitian. Universitas Padjajaran.

Rusyani, E. 2001. Pengaruh Dosis Zeolit yang Berbeda terhadap Pertumbuhan Isochrysis galbana klon Tahiti Skala Laboratorium dalam Media Komersial. Skripsi. Bogor: Institut Pertanian Bogor.

Safitri, M.E., Diantari, R., Suparmono, dan Muhaemin, M. 2013. Kandungan Lemak Total Nannochloropsis sp. pada Fotoperiod yang Berbeda. Jurnal Rekayasa dan Teknologi Budidaya Perairan. 1(2):128-134.

Salim, M.A. 2013. Penggunaan Limbah Cair Tahu untuk Meningkatkan Pertumbuhan dan Produksi Biodiesel dari Mikroalga Scenedesmus sp. 7(1). ISSN 1979-8911.

Soares, J., Loterio, R.K., Rosa, R.M., Santos, M.O., Nascimento, A.G., Santos, N.T., Williams, T.C.R., Nesi A.N., dan Martins, A.M. 2017. Scenedesmus sp. Cultivation Using Commercial-Grade Ammonium Sources. Jurnal Annals of Microbiology. 1-12.

Widayat, dan Hadiyanto. 2015. Pemanfaatan Limbah Cair Industri Tahu untuk Produksi Biomassa Mikroalga Nannochloropsis sp. sebagai Bahan Baku Biodiesel. Reaktor. 15(4):253-260.

Widianingsih, Hartati, R., Endrawati, H., dan Hilal, M. 2011. Kajian Kadar Total Lipid dan Kepadatan Nitzschia sp. yang Dikultur dengan Salinitas yang Berbeda. Ilmu Kelautan. 1-9.

Widianingsih, Hartati, R., Endrawati, H., dan Iriani, V.R. 2012. Kandungan Lipid Total Nannochloropsis oculata pada Kultur dengan Berbagai Fotoperiod. Ilmu Kelautan. 12(3):119-124.

Widjaja, A. 2009. Lipid Poduction from Microalgae As a Promising Candidate for Biodiesel Production. Makara Teknologi. 13(1):47-51. 